\title{
James and Whitehead
}

Assemblage and Systematization of a Deeply Empiricist Mosaic

Philosophy

\section{Paul Stenner}

\section{(2) OpenEdition}

\section{Journals}

Electronic version

URL: http://journals.openedition.org/ejpap/874

DOI: $10.4000 /$ ejpap.874

ISSN: 2036-4091

\section{Publisher}

Associazione Pragma

Electronic reference

Paul Stenner, « James and Whitehead », European Journal of Pragmatism and American Philosophy

[Online], III-1 | 2011, Online since 01 July 2011, connection on 06 May 2019. URL : http://

journals.openedition.org/ejpap/874; DOI : 10.4000/ejpap.874

This text was automatically generated on 6 May 2019.

\section{(c) (†) $\ominus$}

Author retains copyright and grants the European Journal of Pragmatism and American Philosophy right of first publication with the work simultaneously licensed under a Creative Commons AttributionNonCommercial-NoDerivatives 4.0 International License. 


\title{
James and Whitehead
}

\author{
Assemblage and Systematization of a Deeply Empiricist Mosaic \\ Philosophy
}

\section{Paul Stenner}

\section{AUTHOR'S NOTE}

Thanks to Michel Weber, Dennis Soelch and Maria Teixeira for helpful comments on an earlier draft.

\section{Part One}

\section{Assemblage and Systematization}

1 I take the view that Whitehead (1861-1947) systematizes the body of thought assembled by William James (1842-1910). Specifically, I suggest that, via his concept of the actual entity/occasion, Whitehead systematizes James' radical empiricism into a "deep empiricism" that lends new weight and depth to James's vision of a non- or selffoundational 'mosaic' philosophy. These two terms - assemblage and systematization are used by Whitehead in his late book Modes of Thought. System is important, he suggests, but before its work commences we need to attend carefully to the prior work of assemblage. This is because the work of systematization presupposes a restricted collection of primary ideas, and it criticizes these general ideas with specialist methods. Assemblage is the working up, cultivation and entertainment of those more general primary ideas. When systemization is applied to a meager assemblage of ideas, the result is pedantry and exclusion. This sensitivity that Whitehead shows concerning the dangers of premature systematization is important. Consider, for example, that he characterized James' entire intellectual life as "one protest against the dismissal of experience in the interest of system." 3 
2 What is valuable about Whitehead's systematization is that it retains and deepens James' core "radical empiricist" contention that all reality is experiential. ${ }^{4}$ This deepening of radical empiricism, however, extends the concept of experience well beyond James' preferred psychological territory of conscious human experience. In Whitehead's thought the notion of experience becomes an ontological concept that is implicated in all events, whether 'psychological,' 'biological,' 'chemical' or 'physical.' In a memorandum dated exactly a month before his death, James remarked that his system remains "too much like an arch built only on one side." ${ }^{5}$ Whitehead 'rounds' that system out by complementing James' focus on the psychological with attention to territory associated also with the socalled natural sciences. Together, James and Whitehead forge a revolutionary mode of thought, yet to be widely appreciated, that cuts across disciplines, supports progressive political action, and puts ideas, feelings and values back into the world.

\section{On Crystallizing "Vaguely Similar Aspirations"}

William James, with characteristic modesty, expressed the hope that one day his Weltanschauung or pattern of thought might serve as the nucleus for the crystallization of a respectable system of philosophy. Despite this modesty, he was keenly aware towards the end of his life that his type of thought might be part of a "great unsettlement" within modern philosophy which was "on the eve" of a "considerable rearrangement."" Partly because of the priority his thought gives to parts over wholes or to facts over principles, he gave the name "radical empiricism" to his Weltanschauung, and because he considered such facts of experience to be plural, he referred to radical empiricism as a "mosaic philosophy." James identified the gestation at stake in his own style of thinking, not just with the pragmatism of Peirce, Dewey and co., but also with Bergson in France, although he described this as only a "dim identity." Change was in the air of philosophy, and in this atmosphere, he suggests at the beginning of his essay The Experience of Activity, "almost any day a man with a genius for finding the right word for things might hit upon some unifying and conciliating formula that will make so much vaguely similar aspiration crystallize into more definite form." ${ }^{10}$

In the preface to Process and Reality, Whitehead announces just this kind of ambition when he expresses his indebtedness to Bergson, James and Dewey and describes his "preoccupation" as being to "rescue their type of thought from the charge of antiintellectualism." Whitehead greatly admired William James and considered him to have played a key role in the opening of a new epoch in philosophy. In the first chapter of Science and the Modern World he refers to James as an "adorable genius," no less, and in the chapter on science and philosophy he compared James' essay Does Consciousness Exist? with Descartes' Discourse on Method from 1637, attributing to James "the inauguration of a new stage in philosophy." ${ }^{" 11}$ The keynote of this new stage is process, and the articulation of a process ontology requires a radical re-thinking of the concept of an entity.

\section{What is an Entity?}

5 Notwithstanding the high praise, Whitehead saw room for improvement in James' philosophy. ${ }^{12}$ In Does Consciousness Exist?, for example, James insists that consciousness is not an entity, but that it is a function, and that its function is knowing. Whilst Whitehead is in full agreement with the thorough critique of the Cartesian thought substance at play 
here, he nevertheless gently criticizes James for not addressing what he means by an "entity" or by the word "stuff." These words, he points out, do not tell their own story and indeed the notion of an 'entity' is so general that it could mean anything that might be thought about. In this case, even a function would be an entity of sorts.

6 This questioning concerning the meaning of "entity" is not mere wordplay on Whitehead's part. In fact, I suggest that Whitehead's main contribution to the systematization of James' type of thought is his sustained effort to generate a viable concept of 'entity' which, to employ James' terms, does not preclude entities also being functions. The bulk of his philosophy of organism, for example, is devoted to a general clarification of the status of an actual entity. The positive doctrine of Process and Reality, Whitehead states, "is concerned with the becoming, the being, and the relatedness of 'actual entities.' 'Actual entities' - also termed 'actual occasions' - are the final real things of which the world is made up." ${ }^{13}$ Whitehead's notion of an entity is compatible with James' notion of a function, since, as we shall examine in the following section, an actual entity is not a static and stuff-like thing (a thing that endures) but a primary organism whose main characteristic is the activity of patterning possibilities into actualities (a thing that occurs).

7 Effectively, in rethinking the basic concept of "entity," Whitehead is refusing a position according to which some things in the universe are fundamental and static entities, whilst other things, which are not entities in this manner, might instead have the quality of being processes or functions. Whitehead, by contrast, pursues the idea that all actual things are in process. This includes those things that our limited intelligence grasps inadequately as static entities. Seemingly solid and static things like mountains are in fact implicated in such geological processes as plate tectonics and erosion, for instance. Any failure to apprehend this is a function of the relatively short-term duration of unassisted human sensory and cognitive functionings.

That James maintains this taken-for-granted distinction between entity and function is a symptom of the fact that, despite his heightened attunement to process with respect to human psychology, James never systematically developed a fully-fledged process metaphysics. That is to say, he never fully developed an ontology which extends the keynote of process well beyond the activities of human experience to encompass all things. This is not an original claim. As Victor Lowe put it, "the doctrine that experience comes in drops or pulses, each of which is an indivisible unity, is to be found in the psychology of William James; but James never outlined a system of the world on this basis."14 Eisendrath makes a similar point when he observes that "James reforms Descartes by doing away with the soul and allowing the thoughts themselves to achieve subjective unity in the conscious field. His analysis is limited to consciousness; Whitehead's extends to the whole organism." ${ }^{15}$ Again with reference to James' "bud" theory of subjective unity, Pred suggests that although it clearly influenced Whitehead, the latter "went much farther into the formation of the bud than James knew was possible and elaborated a comprehensive monism that was beyond James' reach." ${ }^{16}$ Since I am suggesting that the actual entity concept serves to systemmatize James' notion of pure experience, before turning to "pure experience" I must first examine Whitehead's basic unit. 


\section{Whitehead's Basic Unit: The Actual Entity}

\section{IV. a) The Atomic Nature of Actual Occasions}

Taking seriously the idea that all things might be 'in process' demands considerably more than the recognition of processes like plate tectonics and erosion. To better understand Whitehead's actual occasion/entity concept one must grasp that it is an atomic concept. As a famous mathematician and theoretical physicist prior to his career as a philosopher, Whitehead was more aware than most of the fact that, during his lifetime, "the stable foundations of physics [...] have broken up." ${ }^{17}$ Relativity theory and quantum theory effectively rendered "the old foundations [...] unintelligible," and a core aspect of those old foundations was the idea of irreducible material atoms whose endurance with "simple location" in space supposedly provides the basic building blocks of the universe. Such atoms would supply the bases for all physical processes, but would not themselves be processes. During a relatively short period of time this "mechanical" notion of a passive substratum of self-contained bits of matter gave way to a conception of matter as the modification of energy: sheer activity. In the new scientific view:

The fundamental concepts are activity and process. There are essentially no selfcontained activities within limited regions. These passive geometrical relationships between substrata passively occupying regions have passed out of the picture. Nature is a theatre for the interrelations of activities. All things change, the activities and their interrelations. To this new concept, the notion of space with its passive, systematic, geometric relationship is entirely inappropriate. It has thus swept away space and matter, and has substituted the study of the internal relations within a complex state of activity. This complex state is in one sense a unity. There is the whole universe of physical action extending to the remotest star cluster. ${ }^{18}$

Whitehead was acutely aware of the need for an alternative atomic concept that might replace the now obsolete concept of substance, and in 1920 he put the problem in the following terms: "If we are to look for substance anywhere, I should find it in events which are in some sense the ultimate substance of nature." ${ }^{19}$ Seven years later in Process and Reality his terminology had shifted from events to actual occasions/entities, with the latter defined as the limiting type of event (with just one member). To put it succinctly, Whitehead's doctrine of the actual occasion puts the things that occur (events or occasions) prior to the things that endure (the old concept of "entity") and thus makes the concept of process the atomic basis of all things.

\section{IV. b) The Organismic Nature of Actual Occasions}

11 This way of thinking radically reconfigures our basic modes of thought. The idea of a fundamental material atom had supported a bifurcated conception of the universe in which issues of experience were associated with high-level human subjectivity and kept separate from an objective concept of nature as a brute material externality upon which the concept of experience has no purchase (a "shallow" empiricism). Whitehead's atomic notion of an actual entity, by contrast, is modeled upon the image of a primary organism undergoing an experience. Whitehead thus conceives the kinds of natural actual occasions dealt with in physics as events or occasions "entertaining" and "patterning" a locus of energy: 
Whatever else that [physical] occasion may be, it is an individual fact harbouring that energy. The words electron, proton, wave-motion, velocity, hard and soft radiation, chemical elements [...] all point to the fact that physical science recognizes qualitative differences between occasions in respect to the way in which each occasion entertains its energy. ${ }^{20}$

It should be clear that Whitehead's actual occasion concept is not applicable only to human "experiences" but is an ontological notion that extends a model of experience to all natural processes. Whitehead's "philosophy of organism," in other words, was not content with extending the concept of experience to include the life-processes of biological organisms. For him, the real challenge was to posit a unitary philosophy of radical immanence (with nothing "outside" of nature) capable of expressing the continuity that exists between high-grade human experience, at one extreme, and the subject matter of physics, at the other:

An occasion of experience which includes a human mentality is an extreme instance, at one end of the scale, of those happenings which constitute nature. But any doctrine which refuses to place human experience outside nature, must find in descriptions of human experience factors which also enter into the descriptions of less specialized natural occurrences. If there be no such factors, then the doctrine of human experience as a fact within nature is mere bluff, founded upon vague phrases whose sole merit is a comforting familiarity. We should either admit dualism, at least as a provisional doctrine, or we should point out the identical elements connecting human experience with physical science. ${ }^{21}$

\section{IV. c) The Ontological Nature of Actual Occasions}

As a systematic metaphysician, Whitehead was thus aiming at nothing less than a generic ontological description that, without negating important differences, would be applicable to all actual occasions at all times, from the occasions that compose an electron, through those that compose a single-celled organism, to those which compose the personal being of the reader of this text. This task demands a radical relational rethinking of the old bifurcated subject/object dualism but, importantly, it does not demand its abandonment. On the contrary, the actual entity concept multiplies the subject/object dualism and distributes it throughout the entirety of a nature rethought as an ongoing process of expansion (as new micro experiences build on the expressions of previous micro experiences). Importantly, therefore, the subject/object relation is no longer conceived in epistemological terms as a conscious "knower" representing an objective "known," but in ontological terms as a creative activity (on the part of such an occasion) of lending actual form to the data that composes the inherited universe of that occasion. Each occasion of actuality is the process of a "subject" lending form or pattern to the objects implicated in its momentary field of activity:

Thus the Quaker word "concern," divested of any suggestion of knowledge, is more fitted to suggest this fundamental structure. The occasion as subject has a "concern" for the object. And the "concern" at once places the object as a component in the experience of the subject, with an affective tone drawn from this object and directed towards it. With this interpretation, the subject-object relation is the fundamental structure of experience..$^{22}$

The description Whitehead offers in Process and Reality and his later works amounts to a notion of an actual occasion/entity as an activity of realization whereby a subject concerns itself with its manifold data, patterning them into a novel unity in the process. 


\section{IV. d) The Self-Realizing Nature of Actual Occasions}

15 Whitehead refers to this activity of realization in terms of a complex of prehensions whereby, when those prehensions are "positive" (i.e. when the data are accepted into the constitution of the subject-in-process of formation), the occasion feels its objects, composing them into a configuration. Incompatible aspects of data, on the other hand, are negatively prehended or excluded from actualization. The "experience" at play here is thus not a "representational" matter, as if the prehension were some stage play about a reality occurring elsewhere. Rather, the experience is the activity of realization whereby the "potentiality" immanent in the objects is "actualized" in the form of a real co-creative becoming-concrete (concrescence). Far from being a representational "picture" of a "real world," subjectivity is the very becoming of objectivity.

Through concrescence many things (objects, data) are thus grasped or prehended via a process (i.e. through the becoming of an actual occasion) into a new unity. The many become one. Potentialities, by definition, can be actualized in various different ways, but, in a given occasion, are in actual fact only actualized in one way. "Experience," understood in this Whiteheadian way, is thus a process of conjunctive synthesis. Creativity is central to this process, since something new is added to the universe by the experience (i.e. the pattern itself is added): "[T]he many become one and are increased by one." ${ }^{23}$ Once it is created, however, the experience (i.e. the process of self-realization considered in terms of its own novel internal constitution or in terms of the immediacy of its self enjoyment) enters the actual world as an "expression" that might in turn be "felt" as part of the next occasion of experience. Hence the occasion considered in terms of its own "internal" process of feeling is an "experience" and the occasion considered as the newly available product of this process is an "expression." To use the vocabulary of Process and Reality the experience is the self-becoming of a 'subject' and, once it has become, the result is a "superject" that takes its place as data for future subjects in process of emergence. In this way, the experiencing subject does not pre-exist the objects it prehends (superjects/ expressions), but creates itself through feeling them. Whitehead's principle of relativity is based on this unfolding dynamic whereby the subject (experience) becomes the superject (expression) which in turn becomes the object for a new subject. It therefore "belongs to the nature of every "being" that it is a potential for every "becoming" (Whitehead, 1927-28/1985: 45). Once an actual occasion becomes a determinate superject, then it can play the role of one of the many objects that are the concern of another actual occasion with its process of creative conjunctive synthesis.

\section{IV. e) The Ordering of Actual Occasions Into Discontinuous Continuities (Society and Nexus)}

Since an actual occasion is a pure occurrence that does not endure in time it makes a rather paradoxical "atomic" or "basic" unit. How to account for our routine experiences of continuity and endurance on the basis of the idea that the "completely real things" are happenings and do not endure in time and space? The solution is that routinely encountered things such as buildings, trees, mountains and dogs - which clearly do have histories and endure in space - are not actual occasions. They are more or less coherent orderings of many actual occasions. Such a nexus of occasions can spread itself temporally and spatially, and thus form the basis of time and space. When a nexus (a loose 
arrangement) has its own emergent self-sustaining mode of order, Whitehead refers to it as a society. The occasions that constitute a society thus share a self-sustaining "togetherness" - a definite socially conditioned form that flows from the fact of their mutual prehensions. What we call a "tomato plant," for instance, would be a nexus of occasions involving various societies. Some 'social' occasions are contiguous such that one follows another in a manner that engenders temporal "thickness" or endurance (i.e. temporal order), and some are spatially related contemporaries whose simultaneous activities engender a three dimensional spatial order. These forms of order thus give rise to phenomena that we routinely treat as if we were dealing with a single actuality. For many purposes a society can indeed be treated as a unity and does indeed possess a degree of self-sustaining "individuality," but in fact any such "continuity" must be ultimately be thought in relation to the "discontinuities" (atomic occasions) that compose it. As we shall see later, composition into increasingly complex forms of social order creates the conditions for actual occasions capable of increasingly complex and intense forms of experience, and vice versa.

\section{Whitehead's Ontological Prehension of Jamesian Psychology}

Before turning to James' notion of pure experience, I will further consider how Whitehead appropriates certain aspects of Jamesian thought into his novel ontology, raising the latter's "psychology" to the ontological status of ordered actual occasions. In particular I will suggest that Whitehead's engagement with James' notion of the co-conscious transition informs his solution (just outlined) to the problem of a discontinuous (atomic) basis to natural continuity (or flow).

\section{V. a) Thought is Itself the Thinker (The Creature Creates Itself by Way of Its Feelings)}

19 The distinction between the micro-cosmic (actual occasions) and the macro-cosmic (nexus and society) summarized in section 4.5 explicitly builds upon James' more specific psychology of the "stream of consciousness" in which he describes unified "moments" of "thought" ("micro" atoms) which link together over time ("macro" assemblages). ${ }^{24}$ Indeed, James, at some stage or other, touches upon practically all of the features of an actual occasion rapidly sketched above. The "subject" (momentary "I"), for instance, effects a conjunctive synthesis through "feeling" an immediately past "I" in a novel context. This, for James, is a "transitive" process of self-realization (a bird in flight) that yields a "substantive" (a bird perched) that feeds into the next occasion of the process of becoming. The unification is for James a selective process through which only certain possibilities are actualized, and these "decisions" are implicated in creative development. These features, for instance, are discernable in the following famous quotation:

The I which knows [thoughts] cannot itself be an aggregate; neither for psychological purposes need it be considered to be an unchanging metaphysical entity like the Soul, or a principle like the pure Ego viewed as 'out of time.' It is a Thought, at each moment different from that of the last moment, but appropriative of the latter, together with all that the latter called its own. [...] thought is itself the thinker, and psychology need not look beyond..$^{25}$

Here we have a clear statement of the "atomic" nature of "thought," which is neither "an aggregate" nor a thing "out of time" but instead a series of "moments," where each new 
moment emerges from and "appropriates" its immediate predecessor. James also deals with what he calls the continuity/discontinuity issue quite explicitly in Chapter $\mathrm{X}$ of Some Problems of Philosophy where he articulates an atomic conception of "buds" or "drops" of perception and puzzles over how such a discontinuity-theory (with "certain units of amount bursting into being at a stroke" $)^{26}$ can be reconciled with a theory of continuity ("for if the drops or atoms are themselves without duration or extension it is inconceivable that by adding any number of them together times or spaces should accrue," 155). Each bud or drop is an occasion of conjunctive synthesis that yields a new unity of experience to be inherited in turn by the next "drop." In Chapter 2 of Process and Reality Whitehead makes the case that an actual entity is an act of experience by explicit citation of this passage of text:

The authority of William James can be quoted in support of this conclusion. He writes: "Either your experience is of no content, of no change, or it is of a perceptible amount of content or change. Your acquaintance with reality grows literally by buds or drops of perception. Intellectually and on reflection you can divide these into components, but as immediately given, [106] they come totally or not at all." ${ }^{27}$

\section{V. b) The Example of the Co-conscious Transition}

21 James refers to this most intimate form of "conjunctive relation" as the co-conscious transition - i.e. "the passing of one experience into another when they belong to the same self." James contrasts the ways in which my own experiences are with one another with the ways in which my experiences and your experiences are with one another. Although I can empathize with how you are feeling, I cannot experience your experiences directly - I have a discontinuity-experience in this respect. By contrast, "What I do feel simply when a later moment of my experience succeeds an earlier one is that though they are two moments, the transition from one to another is continuous. Continuity here is a definite sort of experience." Here we can see a) a concept of moments (actual occasions) and b) a concept of their arrangement into a society of such occasions, each following on from the next in a temporal sequence (what James is here calling "continuity"). Insignificant as this may sound, James places great importance onto the co-conscious transition. Consider the following extract from A World of Pure Experience:

Within each of our personal histories, subject, object, interest and purpose are continuous or may be continuous. Personal histories are processes of change in time, and the change itself is one of the things immediately experienced. "Change" in this case means continuous as opposed to discontinuous transition. But continuous transition is one sort of conjunctive relation; and to be a radical empiricist means to hold fast to this conjunctive relation of all others, for this is the strategic point, the position through which, if a hole be made, all the corruptions of dialectics and all the metaphysical fictions pour into philosophy. ${ }^{28}$

To demonstrate the intimacy between the two thinkers on this point, I now quote from Whitehead's Modes of Thought where, having discussed the basic derivation of experience from bodily functioning, he stresses a second equally important source:

But our immediate experience also claims derivation from another source [...]. This second source is our own state of mind directly preceding the immediate present of our conscious experience. A quarter of a second ago, we were entertaining such and such ideas, we were enjoying such and such emotions, and we were making such and such observations of external fact. In our present state of mind, we are continuing that previous state. The word continuing states only half the truth. In one sense it is too weak, and in another sense it overstates. It is too weak, because 
we not only continue, but we claim absolute identity with our previous state. It was our own very identical self in that state of mind, which is of course the basis of our present experience a quarter of a second later. In another sense the word continuing overstates. For we do not quite continue in our preceding state of experience. New elements have intervened. All of these new elements are provided by our bodily functionings. We fuse these new elements with the basic stuff of experience provided by our state of mind a quarter of a second ago. Also, as we have already agreed, we claim an identification with our body. Thus our experience in the present discloses its own nature as with two sources of derivation, namely, the body and the antecedent experiential functionings. ${ }^{29}$

Whitehead here explicitly engages with James, agreeing on the great importance of this kind of experience of transition, but modifying slightly James' emphasis on continuity in order to make more room for his epochal theory of actual occasions (yes, continuity, but also discontinuity as each occasion is an irreducible unity which brings new elements into play). This is a key aspect of Whitehead's effort to "rescue [James', Bergson's, Dewey's] type of thought from the charge of anti-intellectualism" since an over-emphasis on continuity here can lead to the solipsistic form of subjectivism that these thinkers are often charged with. ${ }^{30}$ Whitehead is much clearer than James that causality is at stake in this kind of co-conscious transition (and from two sources), and that this causality forms the hidden bridge between conscious experience and the full variety of events that compose the universe. Whitehead makes this explicit in Adventures of Ideas when discussing causal efficacy (I will return to this in the final section) under the description of non-sensuous perception:

In human experience, the most compelling example of non-sensuous perception is our knowledge of our own immediate past. I am not referring to our memories of a day past, or of an hour past, or of a minute past. Such memories are blurred and confused by the intervening occasions of our personal experience. But our immediate past is constituted by that occasion, or by that group of fused occasions, which enters into experience devoid of any perceptible medium intervening between it and the present immediate fact. Roughly speaking, it is that portion of our past lying between a tenth of a second and half a second ago. It is gone, and yet it is here. ${ }^{31}$

Both philosophers thus give prime significance to James' "co-conscious transition," but Whitehead universalizes this importance via his concepts of the actual occasion and their collection into enduring forms of order, thus extending it well beyond human experience. Actual occasions that include this kind of high level (e.g. conscious) human mentality are at one extreme end of a scale of events that includes all of the happenings that constitute nature. Whitehead, as discussed earlier, is obliged to include this extreme because he refuses to place human nature in a transcendent position "outside" of nature. Features of this description of human experience must therefore also enter into descriptions of less complex, developed and specialized actual occasions (including the flux of energy that characterizes the kinds of natural occasions dealt with by physicists). It is not insignificant that Whitehead ends his last book with the following remarkably clear statement of the key to his philosophy: "[...] the operation of mentality is primarily to be conceived as a diversion of the flow of energy [...]. The key notion from which such construction [of a cosmology] should start is that the energetic activity considered in physics is the emotional intensity entertained in life." ${ }^{32}$

Whitehead's concept of an actual occasion, in sum, is compatible with James' radically empiricist emphasis on experience, and particularly with his notion of discrete "buds" or "drops" of experience, but extends it into the depths of nature (hence "deep 
empiricism"). An actual occasion (or actual entity) is nothing less than an act of experience. ${ }^{33}$ Through this act the "actor" becomes (and "knows") itself through the conjunctive synthesis of many things that are other than itself. This extension makes the concept of process the cosmological keynote. James intuited this but resisted systematizing it. His radical emphasis on experience, for example, was certainly central to his understanding of process, since the "function" of an experience can only be to feed into the becoming of another experience: "According to my view, experience as a whole is a process in time, whereby innumerable particular terms lapse and are superseded by others that follow upon them by transitions which [...] are themselves experiences." ${ }^{34}$

\section{James' Basic Unit: Pure Experience}

Since I am suggesting that Whitehead's concept of actual occasions of experience deepens and systematizes James' prior concept of pure experience we must now briefly examine the latter concept. ${ }^{35}$ "Pure experience" is crucial to James' radical empiricism, and he unfolds it most clearly in two essays from 1904 (Does consciousness exist? and A world of pure experience). For the purpose of making explicit the resonances with Whitehead's concept, it is sufficient to identify the following five aspects of the concept:

\section{VI. a) Materia Prima}

27 Like the actual occasion concept for Whitehead, pure experience functions for James as an alternative to the Cartesian starting point of two substances: "if we start with the supposition that there is only one primal stuff or material in the world, a stuff of which everything is composed, and if we call that stuff "pure experience," then knowing can easily be explained as a particular sort of relation towards one another into which portions of pure experience may enter. ${ }^{36}$ Pure experience is thus the name James gives to the materia prima of everything.

\section{VI. b) Instantaneous Actuality}

28 As with Whitehead's actual entity, James makes the concept of actuality central to pure experience. Pure experience is "plain, unqualified actuality [...] a simple that." ${ }^{37}$ The concept of actuality at play also has a temporal connotation of being instantaneous. Pure experience is thus the "instant field of the present." ${ }^{38}$ As the instant field of the present, a pure experience cannot be true or false or subjective or objective since it just is what it is, a simple that. To draw pure experience closer to Whitehead's basic concept, we might thus fairly call pure experience an actual instant. ${ }^{39}$

\section{VI. c) Virtuality}

As a simple that or actual instant of unqualified experience, however, we need to understand that pure experience is there to be acted upon in the course of a future experience. One actual instant of experience thus shows up, not just as a pure actuality, but as potential for a future instant which might put it to use and qualify it in various ways. A pure experience can therefore be true or false, objective or subjective, in what James calls a virtual sense. Simple actuality is thus always to be conceived in relation to a virtual future experience in process of gestation. This is why James qualifies the "purity" of pure experience as in fact "only a relative term." ${ }^{40}$ The actuality and the virtuality are of equal 
importance and must be grasped together in an unfolding dynamic. One portion of experience is always entering into some sort of a relation with another portion of experience. We imagine a future meal and then we see and smell that meal and then we eat that meal, for instance.

\section{VI. d) The Flux or "Sensational Stream" of the Actuality/Virtuality Dynamic} pure experience in terms of the "immediate flux of life." ${ }^{11}$ This flux pre-exists later forms of reflection and conceptual categorization, for instance, and furnishes them with the material they put to use. Hence if pure experience is a pure actuality, then it is an actuality pregnant with virtual possibilities - it is a that "which is not yet any definite what, tho' ready to be all sorts of whats." Or again, "the flux of it no sooner comes than it tends to fill itself with emphases, and these salient parts become identified and fixed and abstracted; so that experience now flows as if shot through with adjectives and nouns and prepositions and conjunctions." ${ }^{42}$ Such discursively and conceptually ordered sensation is one possible future becoming of the unverbalized flux of feeling that James invokes with the name "pure experience." In a marvelous multiply mixed metaphor, James writes of qualities and definite objects that flower out of a stream of pure experience or sensational stream, only to melt back into it again in the next experience..$^{43}$

\section{VI. e) Mind and Matter as Virtual Possibilities} details of an object known, and it has the potential to be acted upon in relation to the details of a knower that knows an object. Mind and matter, as virtuality actualized, are thus achievements that are the effect of a kind of retrospective doubling or re-entry of pure experience by a later experience. This is essentially what James means when he insists that consciousness is a function rather than an entity: "subjectivity and objectivity are functional attributes solely, realized only when the [pure] experience is "taken," i.e., talked-of, twice, considered along with its two differing contexts respectively, by a new retrospective experience, of which that whole past complication now forms the fresh content." ${ }^{44}$

James writes in this context of the transformation of a day-dream into a conscious reflection in terms of abstracting a certain content and "connecting it to a new group of associates which make it re-enter my mental life." ${ }^{45} \mathrm{He}$ also gives the example of a conscious experience of a pen as contrasted with the simple 'that' of a pure experience of a pen: "The pen, realized in this retrospective way as my percept, thus figures as a fact of "conscious" life. But it does so only so far as "appropriation" has occurred; and appropriation is part of the content of a later experience wholly additional to the originally "pure" pen. That pen, virtually both objective and subjective, is at its own moment actually and intrinsically neither. It has to be looked back upon and used, in order to be classed in either distinctive way. But its use, so called, is in the hands of the other experience [...]." ${ }^{46}$ 


\section{Radical Empiricism and Deep Empiricism}

33 So far, I have suggested that Whitehead systematizes James' pure experience with his concept of the actual entity, and in so doing extends the concept of experience into the heart of nature, thereby deepening radical empiricism. Instead of repeating steps already made elsewhere, I will instead now ask the pragmatic question: What practical difference does this make? My answer concerns what Whitehead calls security of intellectual justification. ${ }^{47}$ Whitehead affords greater confidence about retaining the value of some of the more tendentious and vulnerable aspects of James' thinking. Specifically, these include:

a) his explicit resistance to transcendental explanations and insistence upon the ultimate immanent unity of a plural universe;

b) his "constructivist" stress on the importance of self-generating creativity in a universe in process of creative advance; ${ }^{48}$

c) the notion that together an immanent universe of self-generating creativity is a universe without foundations or rather one that is self-foundationing;

d) his implicit conception of this plural universe as characterized by an internally unfolding "evolution" of different grades of existence which together compose a hybrid or mosaic unity of many regions, and;

e) the importance given to subjective experience, including feelings, emotions and values, which are not split off from broader nature, but taken seriously as natural forms of a most refined and valuable grade.

Together, I group these interrelated features under the label of "deep empiricism." Deep empiricism accepts that "nothing shall be admitted as fact [...] except what can be experienced at some definite time by some experient," ${ }^{49}$ but, following Whitehead, extends the concept of an experient to all of the occasions that collectively constitute the universe. James did indeed suggest such an extension, but he did so rather tentatively and there is no doubt that his experiential home-territory was the domain of experience characteristic of human psychology. James thus writes that we can continue, as radical empiricists, to believe in existence beyond our limited human experience, but:

the beyond must, of course, always in our philosophy be itself of an experiential nature. If not a future experience of our own or a present one of our neighbour, it must be a thing in itself in Dr Prince's and Professor Strong's sense of the term that is, it must be an ex perience for itself whose relation to other things we translate into the action of molecules, ether waves, or whatever else the physical symbols may be. This opens the chapter of the relations of radical empiricism to panpsychism, into which I cannot enter now. ${ }^{50}$

Notwithstanding such clear suggestions as this, to the extent that James tended to draw his philosophy from experiences in the domain of human psychology, his radical empiricism tended towards what we might call a wet empiricism: an empiricism that nourishes itself in the waters of James' famous "stream of consciousness." I would characterize Pred's $\mathrm{s}^{51}$ interesting application of James and Whitehead in this way, since his basic rule of engagement is to "take one's own unverbalized experience in the stream in the moment as a touchstone for one's philosophical claims." Without questioning the undoubted value of this procedure, from a deep empiricist perspective, such streams run along a surface largely innocent of the tectonic heat and pressure raging in the depths. Direct intuitive identification with all modes of experience becomes a major challenge in 
this context, and it becomes necessary to supplement keen attention to one's own stream of experience with speculation ("the play of free imagination, controlled by the requirements of coherence and logic") $)^{52}$ based on a wider pool of data. In thinking Whitehead and James together, it is therefore important to attend to some of the less explicit and focal features of James' thought (his "fringe," as it were). Here I can do no more than schematically fill out the five points just listed:

Point a) resistance to transcendental explanations is an obvious feature of both James and Whitehead. Both reject what I will call the figure of the transcendental unifier. An obvious example would be the rejection of Kant's big idea that the synthesis and integration (unification) of sensation is accomplished by a priori (transcendental) features of the understanding. In the political domain both thinkers also rejected the idea of top-down transcendentally justified political regimes. In both cases, the forms of order that give rise to unification are construed by James and Whitehead as radically immanent: mentality, for instance, is internal to matter and not an externally imposed alterity, and political value is not externally imposed upon otherwise dumb citizens, but cultivated intrinsically. In both examples, in a gesture reminiscent of Spinoza, the figure of the transcendental unifier is replaced with an argument for immanence. The value of immanence is nicely conjured by James' notion of the universe as a "tissue" of experiences within which context new experiences unfold.

This refusal of explanations that unify by a proposed transcendence of experience is of course central to James' definition of radical empiricism according to which "everything real must be experience-able somewhere, and every kind of thing experienced must somewhere be real. ${ }^{13}$ The same challenge is issued emphatically by whitehead: "The explanatory purpose of philosophy is often misunderstood. Its business is to explain the emergence of the more abstract things from the more concrete things. It is a complete mistake to ask how concrete particular fact can be built up out of universals. The answer is, 'In no way.' The true philosophic question is, How can concrete fact exhibit entities abstract from itself and yet participated in by its own nature. ${ }^{24}$ This is summed up in his ontological principle: "no actual entity, then no reason." 55

Point b), concerning constructivism, comes out clearly in this context when James writes that knowledge of sensible realities "comes to life inside the tissue of experience. It is made; and made by relations that unroll themselves in time." ${ }^{56}$ This deep constructivist emphasis on making is decisive to James, and yet extremely vulnerable to dismissal. It is pivotal to his re-thinking of consciousness since, for James, consciousness and matter are not two halves of a doubly composed essential reality. One does not obtain consciousness or matter by a process of subtraction, but by a process of creative addition. Consciousness is a becoming rather than something that already is. James insists on the fact that experiences "become part of our consciousness in their entirety, they become physical in their entirety; and this result is achieved by addition." 57

39 This form of constructivism is to be contrasted with more familiar representational epistemologies in which knowledge is merely a matter of the representation of an external reality by a transcendent knowing mind. To quote Whitehead, it is a matter of "the cumulation of the universe and not a stage-play about it." ${ }^{18}$ It is a matter, to use another Whiteheadian phrase, of creative advance. I suggest the phrase "deep constructivism," as a contrast to, for example, Kant's shallow constructivism which is restricted to the knower or experient whose sense of the world is interpreted as a complex construction. In discussing the manner in which actualities are "pulled" out of virtual 
possibilities, by contrast, James suggests that really "it is the problem of creation; for in the end the question is: How do I make them be? Real activities are those that really make things be, without which the things are not, and with which they are there." 59

James repeats this point when he writes that "the unity of the world is on the whole undergoing increase." This notion that "the universe continually grows in quantity by new experiences that graft themselves upon the older mass" ${ }^{10}$ is more or less clearly expressed by James' metaphor of his radical empiricism as a mosaic philosophy composed of disparate and plural facts. In other words, and here we reach point c), there is no ultimate foundation to the mosaic of experiences. James puts this more prosaically when he likens the bedding that holds together the pieces of an ordinary mosaic to the way in which most philosophies are bedded in transcendental terms such as Substances, transcendental Egos or Absolutes. In the mosaic of radical empiricism there is no such bedding: "it is as if the pieces clung together by their edges, the transitions experienced between them forming their cement." ${ }^{11}$ This is the core of a radically non-foundational mode of thought in which the basis of one experience is another. It is interesting that James identified this feature as the essence of humanism: "though one part of our experience may lean upon another part to make it what it is... experience as a whole is self-containing and leans on nothing." 62

41 Turning briefly to points d) and e), in the essay A World of Pure Experience James offers two similes to contrast absolute idealism with empiricism. The universe of absoluteidealism, he suggests, is like an aquarium or a gold-fish bowl - one can see the fish clearly through the transparent medium of water. Reason can easily penetrate the scene and connect up the parts in lucid fashion. In contrast to this, James invites the reader to imagine the universe of empiricism as "one of those dried human heads with which the Dyaks of Borneo deck their lodges. The skull forms a solid nucleus; but innumerable feathers, leaves, strings, beads, and loose appendices of every description float and dangle from it, and, save that they terminate in it, seem to have nothing to do with one another."63 Compared to the crystal globe of the aquarium, this latter image stresses the imperfect intimacy of various different elements of experience, which are characterized by discontinuity and mixture, having in common only the bare fact of being assembled together. The kind of reason that can make sense of the nucleus of the skull is confounded by the feathers and finds no connections between the other appendages except their bare co-presence.

The mosaic metaphor of radical empiricism sits somewhere between these images of empiricism (the Dyak head) and idealism (the goldfish bowl). The idea expressed by the mosaic metaphor is that there are regions of consistency (goldfish bowls) within a broader (and growing) hybrid totality (Dyak head). Each region of consistency might have its own grade of unity or its own internal connectivity, but the grade of unity proper to one region need not extend to that constituted by the neighbouring piece in the mosaic. The universe of experience forms a hybrid unity composed of numerous grades of unity, each subject to its own "logic." The internal connectivity or consistency alluded to by this phrase "grade of unity" suggests that what makes such a grade consistent is the existence of a shared type of connectivity that runs through it, unifying the many singular experiences (occasions) that compose it. That is to say, the occasions of experience that compose a "grade" are internally connected and connectable one to another, forming, as it were, a self-referential system of operations. 

considered a society in Whitehead's sense of a group of occasions sharing a self-sustaining form of order or mode of "togetherness." Taking the co-conscious transition as an example, it is clear that one occasion of conscious experience connects up with the next occasion, and that this continuing process yields the apparent unity of our "stream of consciousness." A conscious experience cannot connect in the same direct way with, say, a biological event such as the release of a neurotransmitter, or a societal event such as the uttering of a promise. The release of a neurotransmitter might connect directly to the emission of a synaptic electrical charge, but not to a discursive utterance, which can connect directly only to another discursive event. There would thus be a society of neural occasions, a society of conscious occasions and a society of discursive occasions. The heterogeneous assemblage of various different grades taken together would make up a more loosely connected nexus. A promise might not be directly connected to a conscious experience and a chain of neural activity, but it would certainly depend upon the existence of both of these grades of connectivity, and much more besides. To simplify some of the implications of James' mosaic metaphor, I propose consideration of Whitehead's suggestion of a rough division of nature into six loosely distinguishable grades of co-ordinated complexity:

1. Human existence, body and mind.

2. All other animal life.

3. All vegetable life.

4. Single living cells.

5. All large-scale inorganic aggregates.

6. All happenings on the infinitesimal scale disclosed by modern physics.

large-scale inorganic aggregates (a mountain range, for example) are repetitive and conformal and correspond to what we call the physical laws of nature. Although no hard and fast boundary can be drawn between inorganic and organic grades, a single living cell, by contrast to an inorganic aggregate, forms its own bounded micro-system of connectivity. A living cell, for Whitehead, is a structured society of actual occasions that includes within its nexus a number of subordinate non-living societies. Groupings of nonliving molecules, for example, are arranged in intricate structural patterns within the membrane of the cell boundary. The complex internal milieu created by these patterns fosters certain peculiarities of activity (and hence of experience) that are not to be found outside of that milieu. That is to say, a physical molecule is a physical molecule whether located inside or outside a living cell, but the occasions in which it is implicated may differ radically as it moves in and out of the living context of a cell.

We thus have two pieces of James' mosaic, or two broadly distinguishable grades of order (5 \& 4 above). This distinction allows an insight into what quantum physicist Erwin Schrödinger described as the "obvious inability of present-day physics and chemistry" to account for "the events in time and space which take place within the spatial boundary of a living organism." ${ }^{64}$ The price paid for the internal complexity of the living cell is, contra Darwinian dogma, a comparatively fragile, insecure and unstable existence (compared, that is, to inorganic forms). The pattern of a living cell is a delicately balanced and improbable arrangement that is constantly in the process of breaking down and hence constantly in the process of reconstructing itself. This reconstruction requires what we

European Journal of Pragmatism and American Philosophy, III-1 | 2011 
call food - i.e. the stealing away of material from the outside to be used in the reconstruction of the inside.

As we move from 4 to 3, 2 \& 1 we move to even more complex regions of consistency that involve the coordination of many cells that together provide a specialized self-sustaining form order capable of occasions of experience ever more peculiar and rarefied. Compared to a vegetable, an animal body has a highly centralized organization. This means that an animal body contains numerous centres of experience, coordinated into a hierarchy of complexity, such that higher centres receive their data from the expressions of lower centres. Whitehead distinguishes human existence from other animal life, not in absolute terms, but, in part at least, because of the highly centralized control of our bodies via a high-grade brain. As he puts it in a memorable phrase, the human body is "a set of occasions miraculously coordinated so as to pour its inheritance into various regions within the brain." 65

This hybrid mosaic is a plurality, but its pluralism is the product of an "evolution" 66 of sorts from a more primordial flux. James, for example, hints that originally chaotic pure experiences gradually differentiate over time into more orderly grades. Such a view, of course, is consistent with the pluralistic non-foundational constructivist ontology of immanence (i.e. "deep empiricism") shared by James and Whitehead. That is to say, to paraphrase Whitehead, we must explain the emergence of the plural variety of more abstract things from the more concrete things.

\section{Part two}

\section{Transversal Liminality: Parasitism \& Symbiosis}

The remainder of this paper will attend to this key problem of the emergence of more abstract strata (or orders) of experience and expression from more concrete strata, and of the relations between such strata. This problem is at play in Whitehead's notion of a creative advance via phases of transmutation leading gradually from energy to the intensity of human emotion. In the sections following this one I will suggest that Whitehead's concepts of causal efficacy, presentational immediacy and symbolic reference usefully systematize a series of often implicit distinctions made by James between energetic, perceptual, conceptual and discursive orders of experience. A creative synthesis of these two sets of concepts enables an account of how progressively more abstract forms of experience and expression can emerge from more concrete forms, whilst also recognizing that the emergence of a more abstract stratum forever transforms the more concrete modalities. Addressing this issue requires a way of conceptualizing what I will call the transversal and liminal problem of the thresholds between such strata (regions of consistency, grades of unity, modes of connectivity). It is, in other words, one thing to identify the shared form of connectivity proper to a Whiteheadian "society," but quite another thing to grasp the relationships across different grades in the context of a heterogeneous nexus. The classic transversal problems of the inanimate/living, body/ mind, and psychic/societal distinctions have their home in this heterogeneous problemspace ${ }^{67}$ but here I will focus on relations between the distinguishable modes of human experience just mentioned. Both Whitehead and James placed great importance on these transversal questions of liminality. For James, "Experience itself, taken at large, can grow by its edges [...]. Life is in the transitions as much as in the terms connected; often, 
indeed, it seems to be there more emphatically, as if our spurts and sallies forward were the real firing-line of the battle, were like the thin line of flame advancing across the dry autumnal field which the farmer proceeds to burn." ${ }^{88}$ Philosophy, "like life, must keep the doors and windows open." ${ }^{69}$ For Whitehead, life itself is a threshold phenomenon which "lurks in the interstices of each living cell, and in the interstices of the brain." 70

Earlier we saw in this context how James reached for transversal concepts such as "reentry," "appropriation" and being "taken twice." In Principles of Psychology, James approaches the problem as follows:

The highest and most elaborated mental products are filtered from the data chosen by the faculty next beneath, out of the mass offered by the faculty below that, which mass in turn was sifted from a still larger amount of yet simpler material, and so [...]. We may, if we like, by our reasonings unwind things back to that black and jointless continuity of space and moving clouds of swarming atoms which science calls the only real world [note - this would now be identified as level 6 above]. But all the while the world we feel and live in will be that which our ancestors and we, by slowly cumulative strokes of choice, have extricated out of this. $^{71}$

This "filter" metaphor suggests that when a given manifold of experience is re-entered by a new manifold there is a selective appropriation of data at play, such that only certain relevant material is "sifted" and "taken" up into the new manifold. This sifting process is associated with the emergence of a "higher" state or grade of unity from a "lower": "We say [...] a higher state is not a lot of lower states; it is itself. When, however, a lot of lower states have come together, or when certain brain-conditions occur together which, if they occurred separately, would produce a lot of lower states, we have not for a moment pretended that a higher state may not emerge. In fact, it does emerge under those condition." 72

James' filter metaphor gives a neat sense of the abstraction at play in these liminal transitions, since a filter literally "abstracts" a usable selection from a rejected body of material that is sifted away. Eating food is abstraction in this basic sense, and the alimentary canal a sophisticated filter. This kind of image is certainly at play in Whitehead's category of transmutation, in his identification of the explanatory purpose of philosophy with the task of explaining the "emergence of the more abstract things from the more concrete things," and in his claim that the task of philosophy is "to recover the totality obscured by the selection." ${ }^{\prime 73}$ The filter metaphor, however, suggests a rather passive, wholly subtractive and mechanical relation between the experiential grades at play. Whitehead's notion of an actual occasion for which the operation of mentality effects a diversion of the "flow of energy" suggests a more active and additive (contructive) force at play along with this "subtractive" process, as does his notion of food as theft and, more specifically, his analysis of increasingly complicated phases of concrescence which combine the contrasts at play between successive and simultaneous "mental," "physical" and "hybrid" prehensions into cumulatively intense and complex experiential occasions. As Whitehead puts it: "The process of concrescence is divisible into an initial stage of many feelings, and a succession of subsequent phases of more complex feelings integrating the earlier simpler feelings." ${ }^{74}$ This more active and additive (constructive) relation between the occasions of experience of different societies or grades of order is also implied when James occasionally writes of truthful experiences in terms of a subject reaping from its objects a harvest of sensations. 
52 Feeding, harvesting, stealing and diverting are forms of appropriation, "grasping" or selectively prehending. Much as with cooking a meal, the "subtraction" of relevant ingredients is but a stage towards the synthetic process ("addition") of preparing the new unity of a cooked meal. This "active" aspect is clear when Whitehead defines "feeling" technically as the activity by which a concrescent actuality "appropriates" its datum "so as to make it its own." ${ }^{\prime \prime}$ An increase in complexity is made possible by the "taking" (subtraction) and "giving" (addition) whereby a grade of unity profits from the grades in its environment by picking only the 'desired fruits' and harvesting only the 'cream of the crop' for constructive purposes of its own. I have found Serres' notion of parasitism useful in this context, since from one angle this activity resembles, not just the relation of a "superior" to an "inferior," but also the parasite/host relation. ${ }^{76}$ From this perspective, the task of recovering "the totality obscured by the selection" is part of the ethicopolitical art of coordinating a sustainably symbiotic life of shared intensity without selfdefeating exploitation (i.e. a process of balancing the "give and take" involved). For Whitehead, the diversions that lead to increases in the complexity of grades of experience serve first of all to increase the intensity of experience proper to an occasion. The complicated structure of a living cell, for example, means that the occasions at play in its milieu benefit from an amplification of intensity, bought at the cost of stability. Rather than being entirely determined by the past, such occasions ac- quire a responsiveness to the present by which they clutch at vivid immediacy through the capture of intensity. Conscious experience is thus conceived as the experience of a "final percipient" in a long parasitical/symbiotic chain that ultimately leads to the solar energy. The human being, viewed in this way, is quite literally a complex mosaic of disparate forms of order. Our potential for self-creativity is grounded in the fact that we are simultaneously creatures of biochemistry, creatures of consciousness and creatures of communication and culture.

Consciousness and materiality, within this mode of thought, far from being separate substances, are thus extremely contrasted grades of order with characteristic occasions of experience. As James put it "This would be the "evolution" of the psychical from the bosom of the physical, in which the esthetic, moral and otherwise emotional experiences would represent a halfway stage." 77 Between these extremes, however, we should find more complex gradations, and it should be possible to trace the active "filtering" process by way of which more abstract modes of connectivity "emerge" via re-entry, diversion and appropriation of a presupposed external milieu of more concrete connective operations. ${ }^{78}$ I propose that examples of such complex gradations are to be found in James' implicit distinctions between energetics, percepts, concepts and discourse. This assemblage of concepts is systematized by way of Whitehead's idea that symbolic reference "plays the difference" between causal efficacy and presentational immediacy. Finally I suggest a synthesis that provides insights concerning transversal relations between four distinguishable grades of order simultaneously at play in every occasion of human experience.

\section{Energetics $>$ Percepts $>$ Concepts $>$ Discourse}

\section{II. a) Energetics Contrasted with Percepts}

The notion of the evolution of the "psychical from the bosom of the physical" suggests that James was beyond simply suggesting - as in the Does consciousness exist? essay - two complementary ways of acting upon a prior pure experience. It suggests, to re-iterate, 
that what we call the physical is a more primordial grade of order than the "psychical," and that the psychical itself entails some sort of appropriation, re-entry or re-traversal of the physical. The physical would then be a name for one kind of nexus of occasions, and the psychical a name for another manifold that is parasitical, as it were, upon its physical matrix.

This interpretation is consistent with some of James' more enigmatic assertions. For example, James discusses a basic energetic form of shared connectivity by which physical things mutually affect one another. A pipe as a physical thing, for instance, can form a connective group with other such physical things, such as tobacco to put in it, fire to light it with, and so forth. This idea of the pipe as energetically related to comparable physical "associates" can be contrasted with the pipe abstracted as a percept. As a mental percept, the pipe is related to a different society of "associates": it is associated with a manifold of comparable percepts, other images, sensations and perceptions for instance, such as the taste of tobacco and the smell of smoke. James thus evokes an internally consistent society of energetic connectivity, and an internally consistent society of perceptual connectivity, but there is some discontinuity between these types. The energetic pipe can be smoked, but the pipe taken as pure percept has direct relations only to other percepts. In the first context the pipe is taken as a physical entity with its own physical history, process of production in a carpenter's workshop, history of being bought and sold in a shop, of encountering other objects such as tobacco and fire, etc. In the second context it is taken as a connective element in a field of consciousness related to the personal biography of the one having the experience. It may, for instance, be the first pipe the person has ever seen or ever smoked. They can also make the image of the pipe disappear simply by closing their eyes, only to have it replaced by a perception of darkness.

To adopt James' terminology, the same pipe - the pipe of pure experience - can be thought of as being on the intersection of at least two lines, a line of physical history and a line of personal biography. Both lines are equally actual, but rather different in nature. Each experiential line is a creative achievement that is the effect of a retrospective doubling or re-entry of one experience by another. In Jamesian terms, the "virtual" pipe of pure experience is appropriated and used as part of the content of a new experience of the pipe as conscious percept or as energetic physical fact. It can be both to the extent that it is situated on the intersection between the two lines. Here are two examples of James deploying this "energetic/percept" distinction:

[...] speak of the pure unit as "the pen." So far as the pen's successors do but repeat the pen or, being different from it, are "energetically" related to it, it and they will form a group of stably existing physical things. So far, however, as its successors differ from it in another well-determined way, the pen will figure in their context, not as a physical, but as a mental fact. It will become a passing "percept," my percept of that pen. ${ }^{79}$

[...] as the general chaos of all our experiences gets sifted, we find that there are some fires that will always burn sticks and always warm our bodies, and that there are some waters that will always put out fires; while there are other fires and waters that will not act at all. The general group of experiences that act, that [...] wear [their natures] adjectively and energetically, turning them against one another, comes inevitably to be contrasted with the group whose members, having identically the same natures, fail to manifest them in the "energetic" way. I make for myself now an experience of a blazing fire; I place it near my body; but it does not warm me in the least [...] I account for all such facts by calling this whole train of experiences unreal, a mental train. Mental fire is what won't burn real sticks; mental water is what won't necessarily [...] put out even a mental fire. ${ }^{80}$ 
Having indicated the "energetic"/"percept" distinction, James nevertheless insists on their ultimate connection, since both are made of the same basic material of pure experience. Both grades of order are ultimately energetic, but the energy of percepts is radically abstracted and canalized, yielding the strong contrast enabling the distinction. So, having first made the distinction in Does Consciousness Exist?, James immediately adds a footnote to keep the doors and windows open, stressing that "there are also 'mental activity trains' in which thoughts do 'work on each other'." ${ }^{81}$ The society of percepts, in other words, reaps only certain fruits from the energetic harvest that provides its matrix. The new and more abstract economy of perceptual occasions of experience is in this sense parasitical upon groupings of lower grade energetic occasions (perhaps with great symbiotic potential).

\section{II. b) Percepts Contrasted with Concepts}

This first distinction between a group of energetic associates and a comparable but distinct perceptual manifold thus maps broadly onto the subject-object split that is the theme of James' consciousness essay. But James finesses this with other relevant distinctions that allow us to discern more complex gradations. For example, he distinguishes percepts from concepts. Concepts are groupings of non-perceptual associates that are thus distinct both from percepts and from energetics.

Conceptual societies are non-perceptual because they concern the world merely thoughtof and not directly seen, heard or otherwise felt. Where percepts are continuous and meaningless (a perception being just what it immediately is), concepts are discrete, each meaning just what it means. ${ }^{82}$ There is thus a perceptual grade of order which takes the form of a flux of sensation into which data from all of our senses enter in a "big booming buzzing confusion," and there is a conceptual order composed of associates of discrete concepts, "just as real as percepts," ${ }^{83}$ but more abstract. Concepts thus include such nonperceptual experiences as memories and fancies.

Having carved this distinction, James once again keeps the doors and windows open by insisting that "they are made of the same kind of stuff, and melt into each other when we handle them together." ${ }^{14}$ James stresses the distinction between percepts and energetics by writing: "In a picture gallery a painted hook will serve to hang a painted chain by, a painted cable will hold a painted ship." ${ }^{85} \mathrm{He}$ uses the same idea to stress the common ground between percept and concept: "Conception is not like a painted hook, on which no real chain can be hung; for we hang concepts upon percepts, and percepts upon concepts interchangeable and indefinitely." ${ }^{86}$ In fact, however, the relation is not completely interchangeable since percepts come before concepts both phylogenetically ${ }^{87}$ and ontogenetically..$^{88}$ If we "wrap" our percepts in ideas, that is because perceptual experience is prior in both these senses. ${ }^{89}$ Conceptual societies of occasions presuppose and act upon perceptual societies just as percepts presuppose and act upon energetic occasions.

61 Nevertheless, in the environment of a creature capable of conceptual thought, the relation can become interchangeable. Our fancying of a pipe (concept), for instance, might terminate in an encounter with the image of a pipe (percept) that might in turn terminate in a coenesthesic (multi-sensorial) experience of smoking. In this way, James writes about the knowing of a percept by an idea. It is, once again, a question of one experience - a conceptual experience - appropriating and working with the expression of 
another, in this case a perceptual experience. Indeed, this interplay of concept and percept is at the core of James' understanding of pragmatism. His pragmatic rule is that "the meaning of a concept may always be found, if not in some sensible particular which it directly designates, then in some particular difference in the course of human experience which its being true will make." ${ }^{90}$ Concepts are thus tested by way of percepts. There is no fancying of a pipe, and no memory of a pipe without some relation to the perception of a pipe (even if that pipe happens to be momentarily lost). The pipe as concept, to summarize, presupposes the pipe as percept, but, unlike a percept, a concept forms knowledge about an object - and that object may be merely a possible object, a proposition rather than a factually existing perception. The concept, in other words, reaps only certain fruits from the perceptual harvest, creating by abstraction a new economy of connectivity (a society of new and more abstract actual occasions) parasitical upon it, but with great symbiotic potential.

\section{II. c) Concepts Contrasted with Discourse}

62 James hints at a third distinction relevant to our concerns. He does not develop the contrast, but I include it because of its increasing relevance since the postWittgensteinian "turn to language" in philosophy and the "textual turn" in the social sciences and humanities. ${ }^{91}$ The suggestion is that language based communication forms its own distinct grade of order. For the most part, James' comments indicate that this system can distract us both from perceptions and conceptions. He therefore chastises those who are too enamoured with words and who mistake verbal descriptions for concepts, percepts or energetics. In addressing one critic, for instance, he says "all I can catch in their talk is the substitution of what is true of certain words for what is true of what they signify. They stay with words, - not returning to the stream of life whence all the meaning of them came, and which is always ready to reabsorb them." ${ }^{92}$ James also warns that if we are to hold fast to the co-conscious transition we must 'take it at its face value [...] [i.e.] first of all to take it just as we feel it, and not to confuse ourselves with abstract talk about it, involving words that drive us to invent secondary conceptions in order to neutralize their suggestions and to make our actual experience again seem rationally possible." ${ }^{93}$

This last warning also indicates that words and concepts, despite lacking direct connectivity, nevertheless presuppose transversal relations. Words "drive us" to invent concepts, for example, but also each "new book verbalizes some new concept." 94 Discourse exploits conceptual mentality, abstracting from it a new economy of communicative connectivity. Whitehead too draws attention to the ambiguous relations between language and propositions (which he thus refuses to reduce to language). $\mathrm{He}$ regularly warns against trusting linguistic phrases, insisting that language is not the essence of thought (an assumption that has become prevalent since the "textual turn"). Language and thought are, however, thoroughly interwoven, such that it is not going too far to assert "that the souls of men are the gift from language to mankind." 95

\section{Causal Efficacy, Presentational Immediacy and Symbolic Reference}

Energetics, percepts, concepts and discourse - as "curiously incompatible groups" thus candidates for distinguishable grades of experience in James' thought. Each grade 
involves of experiential associates, but each nevertheless shares a common energetic heritage as "pure experience." We can thus see each grade of experience as a piece in a larger mosaic of experience, yielding the immanent unity of a plural universe. The mosaic metaphor, however, is rather flat and two-dimensional. In deepening radical empiricism, I am suggesting that we attend also to the "evolutionary" and transversal aspects that James hints at and that Whitehead develops in more detail. For Whitehead, these grades would be sets composed of cumulatively more complex actual occasions. An "occasion" "bud" or "drop" of conceptual experience must thus be thought of as presupposing and "containing" layers of modified perceptual and energetic experience, the concept being, in a sense "grafted on to the older mass." "The fundamental principle is that whatever merges into actuality, implants its aspects in every individual event." ${ }^{97}$ But given the unified nature of each occasion of experience, once "grafted on" the conceptual element will radically transform any more primitive ingredients. The experiences of us "talking apes" will likewise be forever modified by our powers of language use, since "that experience now flows as if shot through with adjectives and nouns and prepositions and conjunctions." ${ }^{98}$

I suggest that Whitehead's causal efficacy and presentational immediacy are directly comparable to Jamesian "energetics" and "percepts," and that Whitehead thinks what James calls "concepts" in terms of symbolic reference. In a striking passage of Symbolism: Its Meaning and Effect, Whitehead describes the word "experience" as "one of the most deceitful in philosophy"99 and proceeds to analyze it into three modes, "each contributing its share of components to our individual rise into one concrete moment of human experience." ${ }^{100}$ Causal efficacy and presentational immediacy are both modes of perception and symbolic reference is the mode of "conceptual analysis." Presentational immediacy is equivalent to James' percepts because it refers to sense-perception. It is the appearance of the outside world objectified by way of the senses as a constitutive aspect of our experience. It is mediated by qualities like colour, sound, taste and odour implicated in a system of spatial relatedness (spatial extension). This system of spatial extension has an impartial feel: it "presents" to us the immediacy of an external world. This is so whether what is immediately presented be delusional or not: an image of a pipe in a mirror, for example, still involves a set of spatially related colours and shapes, as might a drug induced hallucination. Presentational immediacy is thus characterized by an effect of externality and spatiality, along with a certain barrenness implied by the phrase "mere appearance."

Classic "shallow" empiricism is based upon the assumption that presentational immediacy is the sole perceptual modality. For Hume, causality is a secondary matter, derivative from conceptual thought. For Whitehead it is primary and primitive and it is the basic form of perception: causal efficacy. There are clear links between Jamesian "energetics" and Whiteheadian causal efficacy. James, for example, does in fact use the phrase "causal efficacy" in two essays (The Place of Affectional Facts, ${ }^{101}$ and The Experience of Activity ${ }^{102}$ ), and he explicitly challenges what I have called the "shallow empiricist" assumption that there is no direct perceptual experience of causal efficacy since causality is derivative from conceptual thought and an "illusory projection outwards of phenomena of our own consciousness." 103 We have already touched upon causal efficacy as a mode of non-sensuous perception in the section on the co-conscious transition. What enters our new experience without taking the sensory route is precisely our state of experience from the immediate past, roughly a quarter of a second ago. Causal efficacy is 
"the hand of the settled past in the formation of the present." 104 The patterned product of a prior experience (its expression) provides the bulk of the "data" felt in the course of the next, now actualizing, occasion of experience. The two perceptual sources of experience in this case are thus the causal efficacy of the immediately prior state of mind, and the modifications wrought on the new state by way of experience from bodily functionings associated with the sensory perceptions of presentational immediacy. Causal efficacy is heavy with a sense of derivation from the past and its relevance for the future (its emphasis is temporal), whereas presentational immediacy is a complex and superficial product that halts at the "show" of the externally projected contemporary world of the present (its emphasis is spatial). Causal efficacy arises from a vaguely sensed 'beyond' that shapes us, whilst presentational immediacy projects the clarity of an externality that arises from within.

Since causal efficacy is primitive, it obviously cannot be reduced to this example of coconscious transition. It is, for Whitehead, the dominating and aboriginal experience of lower organisms (the conformal physical feelings of physical occasions are perceptions of causal efficacy). Also, the data from the senses play a double role: we see the pipe (an array of colours and shapes exhibiting the contemporary world as an external special scheme) and we see it with our eyes (our bodily organs imposing their past characters onto the present experience); we smell "the smoke" with our nose and taste it with our palate. Thus "perception in the mode of causal efficacy discloses that the data in the mode of sense- perception [presentational immediacy] are provided by it." ${ }^{105}$ In order to generate its sense of an external spatial world of qualities, sense perception must reap the fruits provided by causal efficacy. In so doing, as with the relation of language to concepts and concepts to percepts, the host risks being obscured from view by the sophisticated constructs of its parasite. Here we are also close to James' idea of reentering and following a pure experience in two complementary (physical and mental) directions: the smoky smell points outwards, to the pipe smoke and its energetic associates; and inwards, to our nasally mediated experience, and its context in a personal biography. Causal efficacy is essentially a reformulation of Spinoza's concept of power as capacity to affect and be affected or, to use Locke's definition, as a twofold relation: "viz. as able to make, or able to receive, any change: the one may be called 'active,' and the other 'passive'." ${ }^{106}$ For Whitehead, "the problem of perception and the problem of power are one and the same."107

Abstracted as two modes of pure perception, neither the powers of causal efficacy nor the percepts of presentational immediacy admit of error. The feeling of the present conforming to the past "just is" that feeling, and the vision of a patch of shaped colour in a spatial array "just is" that vision, irrespective of whether it might refer to a "physical" pipe, a painting of one, or a drug induced hallucination. The key issue now concerns actual occasions whose unity effects a synthesis of the two modes in a manner that combines and contrasts the vague, affectively toned and temporal objectifications of causal efficacy with the spatial externalities of presentational immediacy in a single complex experience. What Whitehead calls 'symbolic reference' involves those occasions (restricted to higher organisms) in which components of presentational immediacy (a shape here, a colour there) are taken as symbols for the components of causal efficacy (an energetic force affecting and being affected by me). This is the most fundamental form of symbolism, defined as the act of taking something (the symbol) for something else (the meaning). The sense data is "taken for" a causally efficacious entity. Such symbolism 
does, of course, admit of error: we risk no error in reporting that we see a roundish patch of brown elongated on one side, but we can be wrong if we correlate this with an energetic object and say we have seen "a pipe": "Thus coloured shapes seem to be symbols for some other elements in our experience, and when we see the coloured shapes we adjust our actions towards those other elements. This symbolism from our senses to the bodies symbolized is often mistaken [...] [but] it is the most natural and widespread of all symbolic modes." 108 For Whitehead, the propositional experience associated with Jamesian concepts emerges precisely from the difference (the contrast) between these two types of perceptual experience.

\section{Synthesis - This is not a Pipe}

69 Finally, I will illustrate my synthesis using Magritte's famous picture of a non-pipe (some of these ideas are developed in greater depth in Psychology without Foundations). ${ }^{109}$ In a visual anti-metaphor, Magritte offers us an image of a pipe under which is painted, albeit in French, "this is not a pipe." I am suggesting that there are three ways in which "this is not a pipe" and hence four different 'pipes' at play in the art-work. Together, when woven into a process theory stressing activity or action they provide a mnemonic for the full spectrum of human experience:

The first pipe corresponds to Jamesian energetics and Whiteheadian causal efficacy, but since the common ground for these is the Spinoza/Locke concept of power, I will name this first pipe power.

The second concerns percepts and presentational immediacy, but since we are dealing with a painting I will stress visual percepts and name it image.

The third concerns Jamesian concepts and Whiteheadian symbolic reference, and I will name it proposition.

The fourth is the linguistic pipe of "discourse," but since an "e" word is required for aesthetic purposes I will take the liberty of naming it enunciation.

With respect to the distinctions, first, Magritte's work suggests a rather obvious distinction between the "power" pipe and its "image." Compared to what we sometimes call a "physical" pipe, the mere image lacks certain powers to affect us and be affected by us. It cannot be touched, smelled or tasted. The physical pipe is multi-sensorial and can be smoked. The distinction is not absolute, however, and the image is better thought of as an abstraction from these prior powers, such that energy is diverted, transformed and canalized. In the process of abstraction to the pipe image, all but the visual aspect is lost. But that image still has powers, albeit powers that are considerably focused and concentrated in comparison to the physical pipe with all of its powers. Here we have causal efficacy contrasted with presentational immediacy. Experiences and expressions of image presuppose and canalize experiences and expressions of power. This [image of a pipe] is not a pipe.

The second distinction Magritte's painting provokes is between the image and the pipe as proposition. Taken as Whiteheadian pure perception, the image is in fact the experience of a spatial array of qualities like shapes and colours. We look up at this coloured shape and say, or think, - there is a pipe. This is an act of symbolic reference in which we albeit unconsciously - make the "leap of faith" of taking the image as a symbol for the physical pipe. It is, in other words, to make a proposition. It is to think something like "I propose that these shapes are a pipe." This leap of faith presupposes the concept of a 
pipe. Were Magritte's painting shown to people from a culture with no experience of pipes, they would be more likely to see it as a more or less interesting coloured shape, or perhaps to misrecognise it as something more familiar. They would not lack the image, but they would lack the concept. This [proposition of a pipe] is not a pipe.

Through symbolic reference, the pipe as propositional experience synthesizes and correlates the pipe as image, on the one side, with the "energetic" pipe and its more extensive powers to affect us and be affected by us, on the other. Often this creative "joining up" achieved by symbolic reference is unproblematic and highly advantageous (we can see things remotely, and then use them intimately), but it is prone to error. Imagine that the painting were so realistic that we were tempted, after making the leap of symbolic reference, to reach out and pick up the pipe from the painting. We would be disappointed as our hand met the flat canvas. We would be like Aesop's dog who drops his piece of meat in order to lunge at its reflection in the still water of a lake. Such an experience may be frustrating, but it is also potentially productive in the provocation it offers. It offers new contrasts for new experiences. We, like the dog, would be confronted, for example, precisely with the difference between what we would call "appearance" (presentational immediacy) and "reality" (causal efficacy). This difference is also the contrast between a mere fact (there I see an image in a still lake) and its importance (there may be something I, a hungry dog, can eat).

Finally, Magritte skillfully lures us to encounter the fact that the discursive enunciation "this is not a pipe" is itself clearly not a pipe with full powers, nor an image, nor a proposition. The linguistically mediated occasion of experience prehends all of these things into a new and more abstract form of unity. To what does the word "this" refer, for example? Does it refer to the image or to the concept? For sure the word 'this' is not a pipe, since we cannot smoke a word. But is the word "this" not also an image? Magritte has certainly taken great care to paint "Ceci n'est pas une pipe" so that it resembles writing, but as part of an artwork, is it not just more image? Magritte himself draws attention to this: "In a painting, words are of the same cloth as images. Rather, one sees images and words differently in a painting." 110 Once again, as we move up from abstraction to abstraction we must recognize that something "energetic" is retained, in more and more canalized form, with every "leap." Language remains causally efficacious, but in a highly circumscribed domain. We can talk about war without getting hurt, and we can talk about pipes without getting burnt. This [enunciation of a pipe] is not a pipe.

In sum, we have multiple ways in which "this" is not a pipe, and these ways shed light on four distinguishable modes of experience. The discursive pipe is not the propositional pipe or any of the others. The propositional pipe is not the pipe image. And the pipe image lacks the causal powers of the energetic pipe. But even the "power" pipe is not the full story, for its "pipeness" is possible only in the context of those complex human forms of life mediated by discursive practice, concepts and so forth, that we "by slowly cumulative strokes of choice, have extricated" from the chaos. Each mode of experience re-enters, appropriates and builds upon experiences from the prior modes. In fact, in a more complete account, it would be necessary to show how the transitions in each mode can be divided into a subjective (experience) and objective (expression) aspect that together provide the epochal basis for process. ${ }^{111}$ Power, for instance, combines the capacity to be affected (experience) with the capacity to affect (expression); image as perceptual experience has its corollary in the motor expressions of sensori-motor 
circuits; speaking/writing (expression) presupposes experiences of listening/reading, and so forth.

Furthermore, with each leap in abstraction or amplification of virtuality, the possibility of error is increased along with the stakes involved in the gamble of futurity. That is why we say "to see is to believe, to touch is to know." To say "to see is to believe" contrasts the risks of mere conceptual thinking with the relative security of perception. But the saying "to touch is to know" contrasts the risks of mere seeing with the comparative security of physical feeling. It goes without saying, of course, that you should not believe everything you read or encounter by mere hearsay.

\section{Conclusion}

In this paper I have suggested that Whitehead's philosophy of groupings of actual occasions serves to systematize James' radical empiricism. The result is a "deep empiricist" process ontology. A self-foundationing plural universe gives rise through time to numerous different grades of order which together compose a mosaic unity. Experience and expression are central to this unity, although, through whitehead, these must not be conflated with high-grade human consciousness. Human experience and expression, although dominated by the abstract deliverances of discursive communication, are in some sense continuous with non-human modes. A synthesis of James and Whitehead in this respect suggests that every discursive exchange implicates, at the very least, conceptual, perceptual and energetic regimes of experience.

\section{BIBLIOGRAPHY}

ATLAN H., (1981), "Hierarchical Self-organization in Living Systems: Noise and Meaning," in Zeleny M. (ed.), Autopoiesis: a Theory of Living Organizations, New York, North Holland, 185-208.

BRADLEY J., (1985), “The Critique of Pure Feeling: Bradley, Whitehead, and the Anglo- Saxon Metaphysical Tradition," Process Studies, 14 (4), 253-64.

BRown S. D., \& P. STEnNER, (2009), Psychology Without Foundations: History, Philosophy and Psychosocial Theory, London, Sage.

EISENDRATH C. R., (1971), The Unifying Moment: the Psychological Philosophy of William James and Alfred North Whitehead, Cambridge, Harvard University Press.

VON FOERSTER H., (1960), “On Self-Organizing Systems and their Environment," in Yovits M. C. \& Cameron S., (eds.), Self-organizing Systems, New York, Pergamon.

foucault M., (1982), This is Not a Pipe, London, University of California Press.

GRIFFIN D. R., (1998), Unsnarling the World-Knot: Consciousness, Freedom and the Mind-Body Problem, London, University of California Press. 
GRIFFIN D. R., (2009), "Panexperientialsim: How it Overcomes the Problems of Dualism and Materialism,"

[anthonyflood.com/griffinpanexperientialism2009.htm].

JACOB F., (1976), The Logic of Life: A History of Heredity, New York, Vintage.

JAMEs W., (1890/1950), The Principles of Psychology, vol. 1, New York, Dover.

JAMES W., (1909), A Pluralistic Universe, London, Longmans Green and Co.

JAMES W., (1911), Some Problems of Philosophy, London, Longmans Green and Co.

JAMES W., (1912/2003: 7), Essays in Radical Empiricism, New York, Dover.

LOWE V., (1941a), “William James and Whitehead's Doctrine of Prehensions,” Journal of Philosophy $38,113-26$.

LOWE V., (1941b), “The Development of Whitehead's Philosophy," in Schilpp P. (ed.), The Philosophy of Alfred North Whitehead, Tudor.

LOWE V., (1985/90), Alfred North Whitehead: the Man and His Work, Johns Hopkins University Press.

LOWE V., (1962), Understanding Whitehead, Johns Hopkins University Press.

LUhMANN N., (1995), Social systems, Stanford, Stanford University Press.

Maturana H. \& F. J. VARela, (1987), The Tree of Knowledge: The Biological Roots of Human

Understanding, Boston, New Science Library.

LUKAS G., (1989), The Rehabilitation of Whitehead: An Analytic and Historical Assessment of Process

Philosophy, State University of New York Press.

MALONE-FRANCE D., (2007), "Hartshorne and Popper on Existential Necessity: A Deep Empiricist

Interpretation," International Journal for the Philosophy of Religion, 57 (3), 193-208.

PRED R., (2005), Onflow: Dynamics of Consciousness and Experience, London, The MIT Press.

RESCHER N., (1996), Process Metaphysics: an Introduction to Process Philosophy, New York, State

University of New York State.

TEIXEIRA M. T. M. V., (2009), "Epochal Time and the Creativity of Thinking: Henri Bergson and Alfred North Whitehead," Concrescence - The Australasian Journal of Process Thought, 77-85.

SCHRÖDINGER E., (1944/90), What is Life?, Cambridge, Cambridge University Press.

SERRES M., (1982), The Parasite, Baltimore, John Hopkins University Press.

SERRES M., (1992), “The Origin of Language,” in Harari J. V., \& Bell D. F., (eds.), Hermes: Literature, Science, Philosophy, Baltimore, John Hopkins University Press.

SINCLAIR S., (2009), “William James as American Plato?,” William James Studies, 4, 111-29.

STENNER P., (2004), "Is Autopoietic Systems Theory Alexithymic? Luhmann and the Sociopsychology of Emotions," Soziale Systeme: Zeitschrift fuer Soziologische Theorie, 10 (1), 159-85.

STENNER P., (2005), “An Outline of an Autopoietic Systems Approach to the Study of Emotion," Cybernetics and Human Knowing, 12 (4), 8-22.

STENNER P., (2008), “A. N. Whitehead and Subjectivity,” Subjectivity 22, 90-109.

WEBER M., (2006), Whitehead's Pancreationsism: the Basics, Paris/Frankfurt/Lancaster, Ontos Verlag. 
WEBER M., (2011), Whitehead's Pancreativism: Jamesian Applications, Paris/Frankfurt/Lancaster, Ontos Verlag.

WEBER M. \& A. WEEKES, (2010), Process Approaches to Consciousness in Psychology, Neoroscience, and Philosophy of Mind, New York, State University of New York Press.

WhITEHEAD A. N., (1920/2004), The Concept of Nature, New York, Prometheus Books.

WHITEHEAD A. N., (1926/85), Science and the Modern World, London, Free Association Books.

WHITEHEAD A. N., (1927), Symbolism: it's Meaning and Effect, New York, Fordham University Press.

WhiteheAd, A. N., (1927-28/1985), Process and Reality, New York, The Free Press.

WHITEHEAD A. N., (1929), The Function of Reason, Princeton University Press.

WHITEHEAD A. N., (1933/35), Adventures in Ideas, Cambrige, Cambridge University Press.

WHITEHEAD A. N. (1934), Nature and Life, London, Cambridge University Press.

WHiteHEAD A. N., (1938/66), Modes of Thought, New York, The Free Press.

\section{NOTES}

1. Lowe (1941 a\&b); Eisendrath 1971; Lukas 1989; Rescher 1996; Griffin 1998; Pred 2005; Weber 2006; Sinclair 2009; Weber \& Weekes 2010; Weber 2011.

2. Malone-France 2007; Stenner 2008; Brown \& Stenner 2009.

3. Whitehead (1938/66: 4).

4. Griffin 2009; Weber 2011.

5. James (1911: viii).

6. James (1912/2003: 21).

7. James (op cit.: 22).

8. James (op cit.: 22).

9. James (op cit.: 81).

10. James (op cit.: 82).

11. Whitehead (1926/85: 177).

12. It should be emphasised here that Whitehead states quite clearly in Science and the Modern World that he did not arrive at his organic conception of the world via psychology and physiology (the route James took), but through his study of mathematics and mathematical physics. He also recognized that other thinkers had, in certain specific ways, gone further in the production of a new settlement of thought than James. He compares James with Descartes on the grounds that neither thinker offered a definitive solution to a philosophical problem, but, on the contrary, both opened new epochs of thought by virtue of their clear formulations. Bergson - whose physiological style of thought kept his epoch 'on the move' - is compared with Locke.

13. Whitehead (1927-28/1985: 18).

14. Lowe (1962: 263).

15. Eisendrath (1971: 41-2).

16. Pred (2005: 141).

17. Whitehead (1926/85: 21).

18. Whitehead (1934: 36).

19. Whitehead (1920/2004: 19).

20. Whitehead (1933/35: 237).

21. Whitehead (1933/35: 237). 
22. Whitehead (1933/35: 226).

23. Whitehead (1927-28/1985: 21).

24. Cf. Teixeira 2009.

25. James (1890/1950: 378-3, 399-400).

26. James (1911: 154).

27. Whitehead (1927-28/1985: 68).

28. James (1912/2003: 26).

29. Whitehead (1938/66: 160).

30. In a 1936 letter to Charles Hartshorne Whitehead compared James to Plato, but also suggested that James 'expressed himself by the dangerous method of overstatement' (cited in Sinclair 2009: 111). In comparing these two quotations relating to the co-conscious transition, I think we can actually witness Whitehead correcting this tendency in James.

31. Whitehead (1933/35: 232-3).

32. Whitehead (1938/66: 168).

33. Whitehead (1927-28/1985: 68).

34. James (1912/2003: 33).

35. I stressed earlier that I am not suggesting that James was Whitehead's only influence here. Another obvious influence is F. H. Bradley's metaphysical notion of feeling (Bradley 1985).

36. James (op. cit.: 3).

37. James (1912/2003: 12).

38. James (op. cit.: 12).

39. Whitehead, however, makes a technical differentiation between the notion of an 'instant,' conceived as a simple primary entity, and an occasion. For Whitehead there are no simple instants, since each instant is always an occasion in which various matters of fact are grouped, ordered or patterned. James, however, is using the word 'instant' in a way that is compatible with a Whiteheadian occasion, hence my decision to risk confusing concept and word here.

40. James (op. cit.: 49).

41. James (op. cit.: 49).

42. James (op. cit.: 49).

43. James (op. cit.: 50).

44. James (op. cit.: 12).

45. James (op. cit.: 113).

46. James (op. cit.: 69).

47. Whitehead (1933/35: 45).

48. I have opted not to tackle the theological aspects of Whitehead's philosophy here. These aspects centre around his notion of eternal objects. This is a very important issue that I do not wish to foreclose on at this point.

49. James (1909: 372).

50. James (1912/2003: 46).

51. Pred (2005: 17).

52. Whitehead (1927-28/1985: 5).

53. James (1912/2003: 83).

54. Whitehead (1927-28/1985: 20).

55. Whitehead (op. cit.: 19).

56. James (1912/2003: 30).

57. James (op. cit.: 30).

58. Whitehead (1927-28/1985: 237).

59. James (1912/2003: 95).

60. James (op. cit.: 47).

61. James (op. cit.: 45). 
62. James (op. cit.: 102).

63. James (op. cit.: 25).

64. Schrödinger (1990: 3-4).

65. Whitehead (1933/35: 243).

66. I use inverted commas here because, as I have merely hinted at, Whitehead offers a valuable critique of Darwinian evolutionary thinking that reframes the dogmas of survival and competition and does away with the metaphysics of scientific materialism (cf. Chapter 1. of Whitehead 1929).

67. Luhmann's concept of irritation is relevant here. Adapting Maturana \& Varella (1985), Luhmann distinguishes organic, psychic and social system types that, being 'operatively closed,' can exert mutual influence only by irritation (Cf. Luhmann 1995). Affectivity can be theorized on this basis (Stenner 2005).

68. James (1912/2003: 45).

69. James (1911: 100).

70. Whitehead (1927-28/1985: 105-6).

71. James (1890/1950: 288-9).

72. James (1890/1950: 162).

73. Whitehead (1927-28/1985: 15).

74. Whitehead (op. cit.: 220).

75. Whitehead (op. cit.: 164).

76. Serres 1982; Stenner 2004, 2005; Brown \& Stenner 2009.

77. James (op. cit.: 19).

78. For comparable arguments in the context of natural science see von Foerster 1960; Jacob 1976; Atlan 1981; Serres 1992.

79. James (op. cit.: 68).

80. James (op. cit.: 17).

81. James (1922: 17, note 21$)$.

82. James (1911: 48-9).

83. James (1912/2003: 101).

84. James (1911: 107).

85. James (1912/2003: 31).

86. James (1911: 107).

87. James (op. cit.: 47).

88. James (op. cit.: 51).

89. James (op. cit.: 109).

90. James (1911: 60).

91. Cf. Brown \& Stenner 2009.

92. James (1912/2003: 55).

93. James (op. cit.: 26).

94. James (1911: 26).

95. Whitehead (1938/66: 35-41).

96. James (1912/2003: 7).

97. Whitehead (1926/85: 187).

98. James (op. cit.: 49).

99. Whitehead (1927: 16).

100. Whitehead (1927: 17).

101. James (op. cit.: 77).

102. James (op. cit.: 85).

103. James (op. cit.: 77).

104. Whitehead (op. cit.: 50). 
105. Whitehead (op. cit.: 53).

106. Whitehead (1927-28/1985: 57).

107. Whitehead (op. cit.: 91).

108. Whitehead (1927: 4).

109. Brown \& Stenner 2009.

110. Cf. Foucault (1982: 38).

111. Methodologically, the events of human experience would thus be composed of a gathered multitude of temporalities expressible as at least four dimensions, intersecting in any given moment: an archeology of enunciations; a genealogy of propositions; a biography of images; and a history of powers.

\section{ABSTRACTS}

This paper contributes to a growing body of philosophical and psychological work that draws parallels between the writings of William James and Alfred North Whitehead1. ${ }^{1}$ In Part One I introduce Whitehead's distinction between assemblage and systematization (section 1) and suggest that Whitehead's philosophy was in part a systematization of James' psychological and philosophical assemblage (section 2). The systematization is based on a rethinking of the entity/ function contrast (section 3) by way of Whitehead's concept of the actual entity/occasion (section 4). This permits a process- oriented ontological extension and James' notion of pure experience (sections 5 \& 6), which yields a deepened version of radical empiricism (section 7). The four sections of Part Two build a more specific argument that James' often implicit distinctions between energetic, perceptual, conceptual and discursive modes of experience can be systematized by way of Whitehead's concepts of causal efficacy, presentational immediacy and symbolic reference. Following the suggestion of Magritte's famous Ceci n'est pas une Pipe artwork, this yields an analysis of the sum of human experience into four progressively integrated factors: power, image, proposition and enunciation.

\section{AUTHOR}

\section{PAUL STENNER}

The Open University

paul.stenner[at]open.ac.uk 